\title{
Performance Study of a Photovoltaic Integrated Solar Dryer for Drying Cabbage
}

\author{
M. K. Ghosal
}

Professor, Department of Farm Machinery and Power, College of Agricultural Engineering and Technology, Orissa University of Agriculture and Technology, Bhubaneswar-751003, Odisha, India

\section{${ }^{*}$ Corresponding Author \\ M. K. Ghosal}

\section{Article History}

Received: 02.10.2019

Accepted: 09.10.2019

Published: 02.11.2019

\begin{abstract}
Drying or dehydration is a simple, low-cost way to preserve food that might otherwise be spoiled. Drying removes water and thus prevents fermentation or the growth of molds. In ancient times, fruits and vegetables were exposed to direct sun light for drying. However, in this method, there are several drawbacks. In the present work, a photovoltaic integrated solar dryer has been fabricated and tested for drying of fruits and vegetables. A d.c. fan powered by photovoltaic cell has been incorporated in the system to create forced air circulation in transferring thermal energy for drying without the use of grid connected power supplies. The dryer has been coupled to a solar air heater having a sun-tracking facility and blackened absorber for enhancing solar energy absorption. The system consists of a photovoltaic panel, solar air heater and a drying chamber with chimney. This system can be used for drying various agricultural products like fruits and vegetables. In this work, the experimental study has been conducted for the forced mode of drying for cabbage.
\end{abstract}

Keywords: Drying, open sun drying, solar dryer, photovoltaic cell.

\section{INTRODUCTION}

Drying is one of the most frequently used operations for preservation of agricultural products [1]. It is essentially a technique for preservation of food materials by reducing the activity of water to a level for enhancing length of desired self-life [2]. In several cases, the drying process is connected to some physical and chemical processes inducing proper internal biochemical and/or microbiological changes, which should take place simultaneously to ensure the characteristic quality features of the product like color, smell, taste, consistence and shape [3]. Drying is an energy intensive process and generally it is defined as the removal of moisture by the application of heat and it is practiced to maintain the quality of product during storage [4]. Fruits and vegetables are seasonal and are highly perishable food products. Preservation of fruits and vegetables is essential for long-term storage without further deterioration in the quality of the products. Various methods such as canning, refrigeration, chemical treatment, controlled atmosphere storage, dehydration etc., are available for their preservation. In rural areas, drying is done only in the direct sunlight without commercial energy consumption; however, it is susceptible to contamination. Solar dryer appears to be a viable and promising way for the preservation of fruits and vegetables [5]. The basic principle behind drying fruits and vegetables is to remove about $80-90 \%$ of the water from the products thereby creating an environment that cannot support microbial life in them. When water is removed from the plant tissues, salt, sugar, protein and other solutes are increased in concentration. This is an additional factor that prevents the growth and reproduction of microorganisms in these products that may cause spoilage. The objectives of the present investigation are to fabricate a simple dryer coupled with a photovoltaic system and to test its performance for drying fruits and vegetables i.e cabbage.

Copyright @ 2019: This is an open-access article distributed under the terms of the Creative Commons Attribution license which permits unrestricted use, distribution, and reproduction in any medium for non commercial use (NonCommercial, or CC-BY-NC) provided the original author and source are credited. 


\section{Materials and Methods}

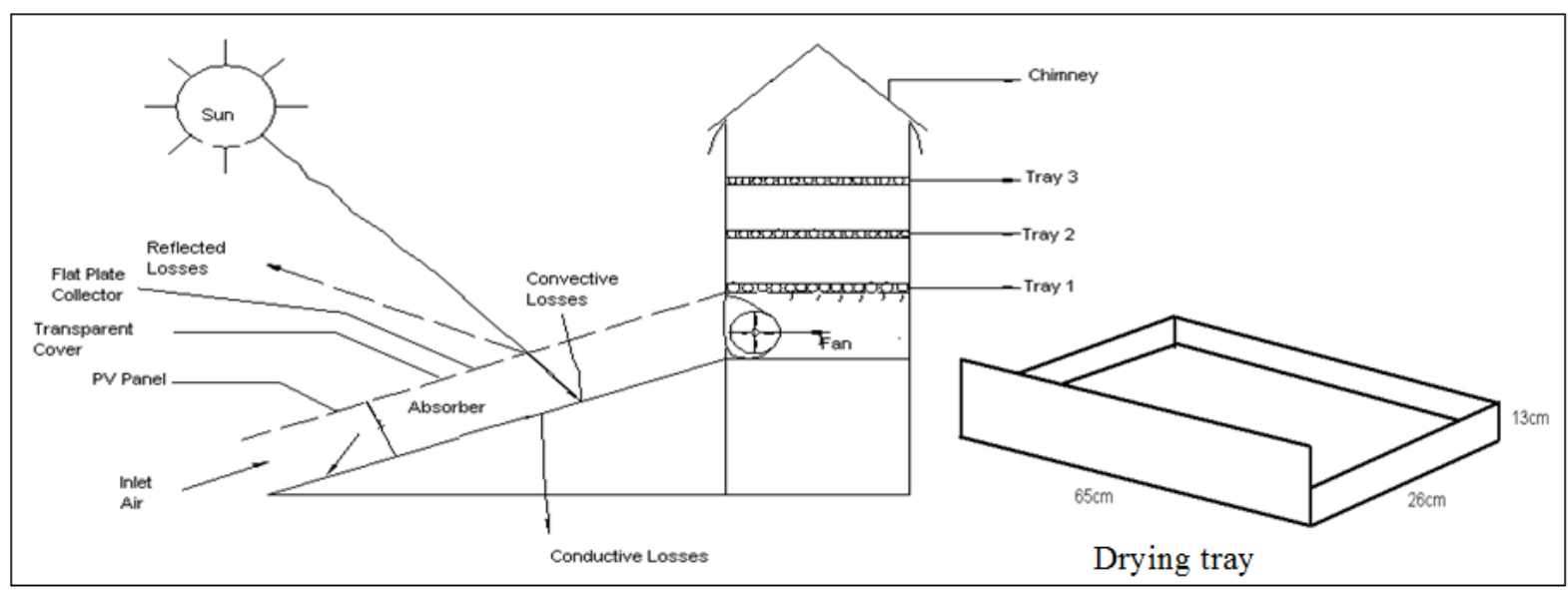

Fig-1: Schematic diagram of a PV integrated solar dryer

An Indirect forced convection PV based solar dryer (Fig-1) was fabricated and studied. It consists of an air heater and drying chamber with chimney and a supporting stand. The air heater consists of an absorber (black painted), plain glass, PV panels, insulation and frame. The air duct beneath the absorber was made from an aluminium sheet $(0.5 \mathrm{~mm}$ thick and $2.2 \mathrm{~m} \times 0.65 \times 0.5 \mathrm{~m}$ in size) through which air was passed. The air duct was made of leak proof and with a good quality sealing material. This unit consists of PV panel (Glass-to-glass) for converting solar radiation into electricity. This panel has been integrated with flat plate collector at of an inclination of $30^{\circ}$ for receiving maximum solar radiation. A fan has been provided in order to extract the heated air available below the air heater and supplying that air into the drying chamber where materials to be dried are placed into the three trays.

\section{Construction details of a PV based solar dryer (Fig-2) \\ PV Module}

PV panel of 35 Watt of dimension $(0.65 \mathrm{~m} \times 0.55 \mathrm{~m})$ has been integrated with the solar dryer. Photovoltaic cells convert solar radiation into electricity which has been utilized for operating / running the fan/ blower. A fan of $12 \mathrm{~V}$ capacity has been provided in order to extract the heated air from air heater and uniformly distributed into the drying chamber.

\section{Solar Collector}

Inclined flat plate collector of dimension (4 mm thick, $0.65 \mathrm{~m} \times 1.66 \mathrm{~m}$ ) is integrated with PV panels, which is placed on the frame of the rectangular box frame along with the U-channel. The glass is fixed with the help of putty to ensure the fixation and leak proof. To prevent insects from entering the dryer, wire mesh was fixed at the inlet side of the collector. The ambient air enters through the inlet and gets heated while passing through air heater and that heated air uniformly distributed by the fan into the drying chamber for drying purpose.

\section{Drying Chamber}

Drying chamber of dimension $(0.65 \mathrm{~m} \times 0.30 \mathrm{~m} \times 0.66 \mathrm{~m})$ is made up of wood and aluminum sheet is covered above the wooden structure. Two sides of the chamber were covered. On the front side of the drying chamber covered with plain glass $(4 \mathrm{~mm}$ thickness, $0.65 \mathrm{~m} \times 0.4 \mathrm{~m}$ in size) for allowing part of solar radiation directly into the drying chamber. From the base to the ceiling of the drying chamber, three wooden trays (on which the product was placed) were stacked evenly at distances of $0.15 \mathrm{~m}$ apart. Chimney is made as outlet for the exhaust air on the top of the drying chamber. Slope roof is made in order to prevent the entry of rainwater.

\section{Trays}

Three trays of dimension $(0.65 \mathrm{~m} \times 0.26 \mathrm{~m} \times 0.04 \mathrm{~m})$ were fabricated and stacked uniformly/ evenly at distances $15 \mathrm{~cm}$ apart, for placing of material to be dried. The tray was made from an aluminum wire mesh $(2.5 \mathrm{~mm} \times 2.5 \mathrm{~mm}$ in size $)$ attached to it. Metal handles (3inch.) attached on each tray for the ease of handling and sliding the trays inside the chamber.

\section{Dryer Stand}

Whole unit or structure is supported by M.S angle (112" $\left.\times 48^{\prime \prime} \times 27.5^{\prime \prime}\right)$ of length $1.22 \mathrm{~m}$ on the drying chamber side and 18 " on the collector end for the vertical positioning of the drying chamber and inclined positioning of PV panel combined solar collector and to give stability to the whole unit. PV based solar dryer has been fabricated and installed for studying the drying of cabbage. The dryer can be used to dry the agricultural and industrial materials using tray-drying system. 


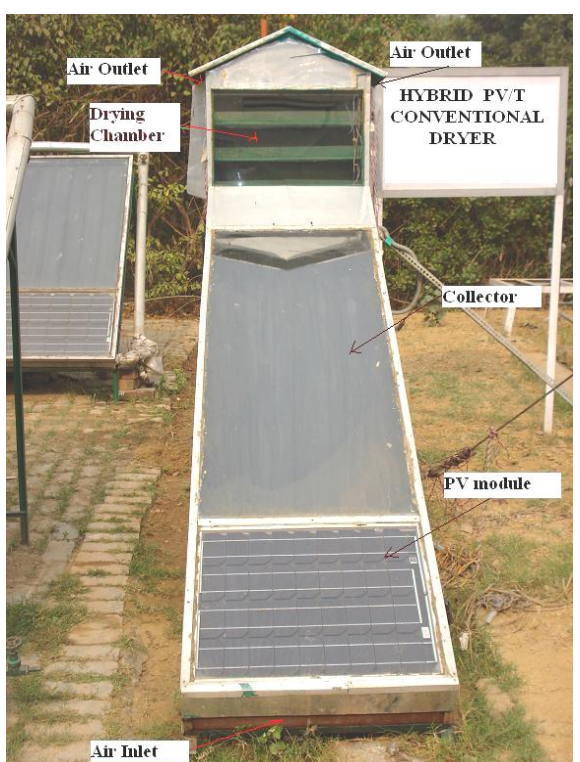

Fig-2: Pictorial View of a PV Integrated Solar Dryer

\section{Instrumentations and Measurements}

In the fabricated PV based solar dryer, two thermocouples have been positioned to measure the air temperature at the inlet and outlet portion of the air heater. Another three thermocouples have been placed at tray-1, tray-2 and tray- 3 in order to measure the temperature of trays. Ambient temperature is also recorded during the course of experiments with the help of mercury thermometer near the solar dryer under the shade. Solarimeter was used for measuring the solar radiation on an inclined surface. Wind speed was measured with an anemometer and airflow rate in the collector was determined by measuring the air velocity at the collector outlet. For measuring the weight loss of the sample, an electrical balance was used. No load and load tests were performed on sunny days and hourly values of air temperatures, air velocity and solar irradiance were recorded for three sunny days. Digital Clamp meter/ Tong meter a conventional instrument, used to measure load current $\left(\mathrm{I}_{\mathrm{L}}\right)$, load voltage $\left(\mathrm{V}_{\mathrm{L}}\right)$, short circuit current $\left(\mathrm{I}_{\mathrm{sc}}\right)$ and open circuit voltage $\left(\mathrm{V}_{\mathrm{oc}}\right)$.

\section{Experimental Observations}

The observations have been recorded during summer period. The hourly variations of solar intensity, various temperatures namely ambient air, inlet and outlet air temperature of air heater, tray-1, tray-2, tray-3, air velocity (forced mode only) have been measured. The following parameters are measured or recorded during the course of experiments.

Solar radiation on an inclined surface $\left(\mathrm{I}_{\mathrm{Tt}}\right)$; Ambient temperature (Inlet temperature $\left.\mathrm{T}_{\mathrm{a}}\right)$; Outlet air temperature (To); Tray-1 temperature $\left(\mathrm{T}_{1}\right)$; Tray-2 temperature $\left(\mathrm{T}_{2}\right)$; Tray-3 temperature $\left(\mathrm{T}_{3}\right)$; air velocity or flow rate of air $\left(\mathrm{V}_{\mathrm{a}}\right)$; Load current and load voltage; Short circuit current and open circuit voltage.

\section{RESULtS AND Discussion}

The experiments were conducted on no load condition and the performance of the PV based solar dryer has been presented in this section. No load test of dryer has been conducted to measure the temperature of air heater and drying chamber. Under this condition, the useful heat is extracted but it is not utilized. A fan extracts the thermal energy of the hot air from the air heater and transfers it to the drying chamber and thus trays inside the drying chamber can attain the required temperature. Thermocouples have been used to measure the temperatures of inlet, outlet air of air heater and the trays. Glass in mercury thermometer is used to measure the temperature of ambient air. All the temperatures have been recorded at an interval of one hour. Load current, load voltage, short circuit current and open circuit voltage have been measured with the help of tong meter on an hourly basis. The data from the experimental observations both on clear sunny day and partly cloudy day are shown in the Tables 1 and 2. 
Table-1: Experimental observations in a partly cloudy day

\begin{tabular}{|c|c|c|c|c|c|c|c|c|c|c|c|c|c|c|}
\hline Time & Inlet & Outlet & Tray1 & Tray2 & Tray3 & Exhaust & \multicolumn{3}{|c|}{ Solar radiation } & \multicolumn{2}{|c|}{ PV panel } & \multicolumn{2}{|c|}{ Load } & \multirow{2}{*}{$\begin{array}{c}\begin{array}{c}\text { Air } \\
\text { velocity }\end{array} \\
V_{a}\end{array}$} \\
\hline$T$ & $\mathrm{~T}_{\mathrm{a}}$ & $\mathrm{T}_{0}$ & $\overrightarrow{T_{1}}$ & $\mathrm{~T}_{2}$ & $\mathrm{~T}_{3}$ & $\mathrm{~T}_{\mathrm{e}}$ & $I_{T h}$ & $l_{\mathrm{dh}}$ & $\mathrm{I}_{\mathrm{Tt}}$ & $V_{o c}$ & $I_{s c}$ & $V_{L}$ & $\overline{I_{L}}$ & \\
\hline Hrs. & $\left({ }^{\circ} \mathrm{C}\right)$ & $\left({ }^{\circ} \mathrm{C}\right)$ & $\left({ }^{\circ} \mathrm{C}\right)$ & $\left.{ }^{\circ} \mathrm{C}\right)$ & $\left({ }^{\circ} \mathrm{C}\right)$ & $\left({ }^{\circ} \mathrm{C}\right)$ & $\mathrm{W} / \mathrm{m}^{2}$ & $\mathrm{~W} / \mathrm{m}^{2}$ & $\mathrm{~W} / \mathrm{m}^{2}$ & volt & amp & volt & amp & $\mathrm{m} / \mathrm{s}$ \\
\hline 9.00 & 30 & 37 & 36.5 & 36 & 35.1 & 34.6 & 340 & 48 & 300 & 16.1 & 1.6 & 15.4 & 0.3 & 2.7 \\
\hline 10.00 & 30.5 & 39 & 38.5 & 38 & 37.2 & 36.4 & 380 & 52 & 340 & 16.0 & 1.5 & 15.6 & 0.3 & 3.2 \\
\hline 11.00 & 31 & 40.2 & 40 & 39.1 & 38 & 37.5 & 420 & 60 & 400 & 16.3 & 1.4 & 15.3 & 0.3 & 3.8 \\
\hline 12.00 & 31.5 & 41.3 & 40.6 & 40.1 & 39.3 & 38.7 & 460 & 70 & 420 & 16.8 & 1.7 & 15.4 & 0.4 & 3.5 \\
\hline 13.00 & 32 & 42.1 & 41 & 39 & 38.2 & 37.4 & 486 & 56 & 456 & 16.4 & 2.2 & 16.1 & 0.4 & 3.2 \\
\hline 14.00 & 31.5 & 42 & 40 & 39 & 38 & 37 & 500 & 40 & 400 & 15.9 & 1.8 & 15.8 & 0.3 & 3.1 \\
\hline 15.00 & 29 & 40 & 39.4 & 38.3 & 37.4 & 36 & 370 & 36 & 290 & 15.6 & 1.4 & 15.5 & 0.3 & 3.3 \\
\hline 16.00 & 27 & 38 & 37 & 36.3 & 35.5 & 35 & 300 & 30 & 260 & 15.1 & 1.0 & 15.3 & 0.2 & 2.5 \\
\hline
\end{tabular}

Table-2: Experimental observations in a clear sunny day

\begin{tabular}{|c|c|c|c|c|c|c|c|c|c|c|c|c|c|c|}
\hline Time & Inlet & Outlet & Tray1 & Tray2 & Tray3 & Exhaust & & ar radia & & PV & anel & & & Air \\
\hline$T$ & $\mathrm{~T}_{\mathrm{a}}$ & $T_{0}$ & $T_{1}$ & $T_{2}$ & $T_{3}$ & $\mathrm{~T}_{\mathrm{e}}$ & $I_{T h}$ & $I_{\mathrm{dh}}$ & $I_{T t}$ & $V_{o c}$ & $I_{s c}$ & $V_{\mathrm{L}}$ & $I_{L}$ & $V_{a}$ \\
\hline Hrs. & $\left({ }^{\circ} \mathrm{C}\right)$ & $\left({ }^{\circ} \mathrm{C}\right)$ & $\left({ }^{\circ} \mathrm{C}\right)$ & $\left({ }^{\circ} \mathrm{C}\right)$ & $\left({ }^{\circ} \mathrm{C}\right)$ & $\left({ }^{\circ} \mathrm{C}\right)$ & $\mathrm{W} / \mathrm{m}^{2}$ & $\mathrm{~W} / \mathrm{m}^{2}$ & $\mathrm{~W} / \mathrm{m}^{2}$ & volt & amp & volt & amp & $\mathrm{m} / \mathrm{s}$ \\
\hline 9.00 & 34.5 & 45.5 & 45 & 44.5 & 44 & 43.5 & 570 & 105 & 530 & 16.6 & 1.5 & 16.5 & 0.4 & 2.9 \\
\hline 10.00 & 35 & 46 & 45.5 & 45 & 44.5 & 44 & 610 & 110 & 570 & 16.5 & 1.7 & 16.2 & 0.4 & 3.5 \\
\hline 11.00 & 36 & 46.5 & 46 & 45.5 & 45 & 44.5 & 780 & 130 & 710 & 16.3 & 1.8 & 15.3 & 0.4 & 3.8 \\
\hline 12.00 & 37 & 48.5 & 48 & 47.5 & 47 & 46.5 & 820 & 150 & 800 & 16.8 & 2.1 & 16.4 & 0.5 & 4.1 \\
\hline 13.00 & 37.5 & 47.5 & 47 & 46.5 & 46 & 45.5 & 840 & 170 & 700 & 16.4 & 1.9 & 16.1 & 0.5 & 3.9 \\
\hline 14.00 & 38 & 47.5 & 47 & 46.5 & 46 & 45.5 & 860 & 160 & 680 & 15.9 & 1.8 & 15.5 & 0.4 & 4.1 \\
\hline 15.00 & 38.5 & 46.5 & 46 & 45.5 & 45 & 44.5 & 720 & 165 & 540 & 15.6 & 1.4 & 15.4 & 0.3 & 3.3 \\
\hline 16.00 & 39.5 & 45.5 & 45 & 44.5 & 44 & 43.5 & 630 & 150 & 310 & 15.1 & 0.8 & 15 & 0.2 & 2.5 \\
\hline
\end{tabular}

From the tables it is seen that the outlet temperature of air heater is higher by $8-9{ }^{\circ} \mathrm{C}$ than ambient air temperature. The temperatures of air decrease with its passage of travel in the drying section. The temperature of air in tray- 1 is more followed by tray- 2 and tray-3. The exhaust air temperatures were found to less than the inlet air temperature and the temperatures of air in drying zones resulting in the drying of the material in the dryer unit. Load currents and voltages were also found to be more in clear sunny days than in cloudy days.

\section{Performance of Dryer on Load Condition}

The fresh and fully matured cabbage was collected from the local market. The upper covering leaves which are generally not consumed were removed. After removing the non-consumable parts, the cabbage was cut into small pieces of about $2 \mathrm{~cm}$ length with the help of a stainless steel knife. Sliced pieces were washed under tap water to remove dust, dirt and other impurities adhered to the material. Actual performance of dryer can be judged only through load testing i.e. the quantity of useful heat extracted and utilized to remove the moisture from the material placed on trays inside the drying chamber. Thermocouples were placed on each tray and temperatures were recorded at an interval of one hour.

Initial moisture content of the material was determined by standard oven drying method. Samples were prepared and spread uniformly in trays and trays were put inside the dryer. Three sample trays of size $(60 \times 30 \times 5) \mathrm{cm}$ each were used to study the rate of drying of the material. The weight of sample in each tray was recorded at an interval of one hour to determine the quantity of moisture removed. Drying was continued till the moisture content of product reduced to its safe and equilibrium level and the performance of the dryer on load condition has been mentioned in Table-3. 
Table 3: Drying behaviour of cabbage in the solar dryer Drying of cabbage in first day

\begin{tabular}{|c|c|c|c|c|c|c|}
\hline Time & $\begin{array}{l}\text { Wt. of product in } \\
\text { tray-1 (gm) }\end{array}$ & $\begin{array}{l}\text { Wt. of product } \\
\text { in tray-2(gm) }\end{array}$ & $\begin{array}{l}\text { Wt. of product } \\
\text { in tray-3(gm) }\end{array}$ & $\begin{array}{l}\text { Wt. of water } \\
\text { removed in tray- } \\
1(\mathrm{gm})\end{array}$ & $\begin{array}{l}\text { Wt. of water } \\
\text { removed in tray- } \\
2 \text { (gm) }\end{array}$ & $\begin{array}{l}\text { Wt. of water } \\
\text { removed in tray- } \\
3(\mathrm{gm})\end{array}$ \\
\hline $11 \mathrm{am}$ & 446.5 & 477.6 & 468 & & & \\
\hline $\begin{array}{c}12 \\
\text { noon }\end{array}$ & 345.5 & 379.7 & 391.6 & 101 & 97.9 & 76.4 \\
\hline $1 \mathrm{pm}$ & 291.1 & 328.5 & 343.6 & 54.4 & 51.2 & 48 \\
\hline $2 \mathrm{pm}$ & 253 & 290.7 & 305 & 38.1 & 37.8 & 38.6 \\
\hline $3 \mathrm{pm}$ & 226.5 & 262.2 & 276.1 & 26.5 & 28.5 & 28.9 \\
\hline $4 \mathrm{pm}$ & 212.1 & 246.3 & 259.2 & 14.4 & 15.9 & 16.9 \\
\hline \multicolumn{7}{|c|}{ Drying in second day } \\
\hline $\begin{array}{l}10 \\
\mathrm{am}\end{array}$ & 188.9 & 241.2 & 254.3 & & & \\
\hline $11 \mathrm{am}$ & 159.2 & 199.4 & 211.9 & & & \\
\hline $\begin{array}{c}12 \\
\text { noon }\end{array}$ & 140 & 174.5 & 180.9 & & & \\
\hline $1 \mathrm{pm}$ & 126.8 & 155.9 & 162.1 & & & \\
\hline $2 \mathrm{pm}$ & 112.6 & 137 & 142.7 & & & \\
\hline $3 \mathrm{pm}$ & 101.3 & 121.3 & 126.4 & & & \\
\hline $4 \mathrm{pm}$ & 96.9 & 114 & 118.7 & & & \\
\hline \multicolumn{7}{|c|}{ Drying in third day } \\
\hline $10 \mathrm{am}$ & & 112.9 & 110.9 & & & \\
\hline $11 \mathrm{am}$ & & 92.4 & 98 & & & \\
\hline
\end{tabular}

It was observed that on second day, optimum drying was taken place in tray-1 and on third day, optimum drying was taken place in trays -2 and 3.

\section{CONCLUSIONS}

- The outlet temperatures of air heater go on increasing with the increase in solar radiation. The outlet temperatures of air heater change with climatic conditions and time in a day.

- The outlet temperatures in the dryer were found to be around 8-9 ${ }^{\circ} \mathrm{C}$ higher than that of the ambient air temperature (inlet air temperatures) which indicate the quick and effective drying of agricultural products as compared to traditional drying.

- On second day of experimentation, optimum drying was taken place in tray-1 and on third day, optimum drying was taken place in trays -2 and 3 on load condition.

\section{REFERENCES}

1. Mujumdar, A. S. (2004). Emerging dehydration technologies for preservation of agro-products. International Conference on Emerging Technologies in Agricultural and Food Engineering. Indian Institute of Technology Kharagpur, India, 14-17.

2. Mahapatra, A. K. \& Imre, L. (1989). Role of solar agricultural drying in developing countries. International Journal of Ambient Energy, 10(3), 163.

3. Sharma, V. K., Sharma, S., Ray, R. A., \& Garg, H. P. (1986). Design and performance studies of solar dryer suitable for rural application. Energy Conversion and Management, 26, 111-119.

4. Purohit, P., \& Kandpal, T. C. (2005). Solar crop dryer for saving commercial fuels: A techno-economic evaluation. International Journal of Ambient Energy, 26(1), 3-12.

5. Jain, D., \& Tiwari, G. N. (2002). Effect of Greenhouse on Crop Drying under Natural and Forced Convection. Energy Conversion and Management, 45, 765-783. 